\title{
High Strain Rate Dynamic Deformation of ADI
}

\author{
Dawid Myszka ${ }^{1, a^{*}}$, Mostafa Ahmed ${ }^{2, b}$, Adel Nofal ${ }^{2, c}$, Emilia Skolek $^{1, d}$, \\ A. Hussein ${ }^{3, e}$ \\ ${ }^{1}$ Warsaw University of Technology, Warszawa, Poland \\ ${ }^{2}$ Central Metallurgical R\&D Institute, Cairo, Egypt \\ ${ }^{3}$ Cairo University-Faculty of Engineering \\ amyszkadawid@wp.pl, ${ }^{b}$ mostafa.a-othman@hotmail.com, cadelnofal@hotmail.com \\ demilia.skolek@gmail.com, ${ }^{\mathrm{e}}$ aahussein41@yahoo.com
}

Keywords: Taylor impact test, high dynamic deformation, austempered ductile iron (ADI), intercritically austenitizing ductile iron (IADI), TRIP Phenomenon.

\begin{abstract}
Engineering materials used in numerous applications, particularly in automotive crash loading and military ballistic purposes have to meet new demands, one of which is the resistance to dynamic loading. As the phenomena associated with such interaction is rather complex, non-static types of tests are applied to evaluate and compare between different potential materials. In this Work, different grades of ADI were produced under different austenitizing and austempering conditions different ausferrite morphologies. The effect of alloying elements such as $\mathrm{Cu}$ and Mo on the initial microstructure of the ductile iron was also studied. The initial amount of retained austenite was subjected to different dynamic strain rates. The hardness and strain induced martensitic transformation as a function of the microstructure and strain rate were evaluated. Extensive use of XRD and SEM was made to evaluate the high strain rate properties of the investigated grades.
\end{abstract}

\section{Introduction}

Austempered ductile irons (ADI) with its unique ausferritic microstructure which have superior mechanical and physical properties. The superior properties of ADI nominate it to be used in special applications, such as parts used in machinery for agriculture and mining as well as military ballistic purposes where service combine conditions of impact and abrasive wear. By using ADI in these application, it must meet new demands, one of which is the resistance to dynamic loading. As the phenomena associated with such interaction is rather complex, non-static types of tests are applied to evaluate and compare between different potential materials.

Conventional mechanical tests cannot replicate conditions of high strain rate dynamic deformation, and special tests are needed to reliably predict the dynamic behavior of the materials. One of these special types of tests is Taylor impact test, which defines the dynamic yield strength level for a material that is rapidly, or impulsively, loaded. Taylor impact tests are performed by impacting a cylindrical projectile (investigated material) on an anvil at a high velocity.

When a high speed projectile reaches the anvil, a wave of compressive stresses will be generated at the projectile/anvil interface, then the stress wave will be divided into two components. The first one is an elastic compressive wave, moving through the material at the speed of sound. The amplitude of the stress level behind the compressive wave front is below the yield strength of the material. The second component, a plastic compressive wave, will follow the elastic compressive wave at a greatly reduced velocity. At the plastic front, the stress level exceeds the yield strength of the material. The high compressive stress causes severe deformation to occur in the form of radial motion outward away from the specimen axis (Mushroom growth), accompanied by shortening of the projectile length. When the elastic compressive wave arrives at the end of the projectile, it is reflected as a tensile wave of equal magnitude. The tensile wave will move through the specimen until it encounters the plastic compressive wave front, located within the specimen (see fig 1). The motion of the elastic wave and the interaction with the plastic compressive wave will have two 
important effects. First, the velocity of the plastically undeformed portion of the projectile will be reduced as the elastic wave moves through the material. Second, the reflected tensile wave will superimpose with the compressive plastic wave to reduce the overall stress at the plastic wave front. After repeated occurrences, the motion of and stress within the specimen will both be reduced to zero [1].
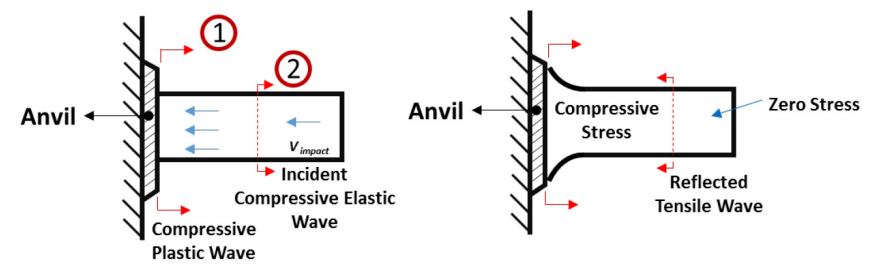

Fig. 1. Plastic and Elastic Waves Motion in the Taylor Test Specimen

As mentioned above, ADI has excellent physical and mechanical properties, these excellent properties are related to its unique microstructure, which consists of ferrite $(\alpha)$ and high carbon austenite $\left(\gamma_{\mathrm{HC}}\right)$. It is now well established [2-3] that the important microstructural parameters that enhance the mechanical properties of ADI are: volume fraction of austenite, $X_{\gamma}$ ); carbon content of the austenite $\left(C_{\gamma}\right)$ as well as morphology of the ausferrite.

A considerable number of research investigations in the strain hardening behavior of ADI [2-4] have been conducted by employing tensile testing and different deformation experiments. It has been reported that strain-hardening behavior of different ADI grades is very sensitive to microstructural constituents and the retained austenite is the most important variable. Austenite in ADI has two types of retained austenite, stable and reacted austenite. It has been reported that the strain hardening phenomena which may occur in ADI is attributed to the stability of austenite which exist in the microstructure of ADI during deformation. The ADI grades austempered at higher temperatures (e.g. $370-400{ }^{\circ} \mathrm{C}$ ), this ADI grades have greater tendency to produce strain induced martensite after deformation and this could be attributed to the larger volume fraction of the retained austenite in these irons. Meanwhile, at low austempering temperature (e.g. $260{ }^{\circ} \mathrm{C}$ ), the presence of ferrite in large amounts in close proximity to the austenite, also prevents formation of strain-induced martensite.

The main objective of this investigation is studying the effect of high strain deformation on the microstructure of ADI and correlated to the TRIP phenomenon (Transformation Induced Plasticity) arising from transforming retained austenite into martensite due to the high strain deformation.

\section{Experimental Work}

\section{Materials}

The material used in this study was obtained in the experimental foundry of the Central Metallurgical for Research \& Development Institute (CMRDI)-Egypt, using a medium frequency $100 \mathrm{~kg}$ capacity induction furnace. Two groups of ductile iron were used in this investigation; the chemical composition of group 1 was as follows; C: $3.84 \%, \mathrm{Si}: 2.63 \%, \mathrm{~S}: 0.02 \%, \mathrm{P}: 0.015 \%$, $\mathrm{Mg}: 0.04 \%$, Mn: 0.2\%, Fe: Bal. the second group (group 2) of this investigation had the same chemical composition of group 1 but alloyed with $\mathrm{Cu}: 0.6 \%$, and $\mathrm{Mo}: 0.25 \%$. The material was originally cast in the form of Y-blocks with $25 \mathrm{~mm}$ thickness.

\section{Heat Treatment}

The ductile iron (DI) samples were subjected to two different types of heat treatment:

i. Conventional heat treatment, where the samples were austenitized at $900{ }^{\circ} \mathrm{C}$ for $45 \mathrm{~min}$ and then quenched and austempered in a molten salt bath at $275^{\circ} \mathrm{C}$ and $375^{\circ} \mathrm{C}$ for $45 \mathrm{~min}$.

ii. Intercritically partial austenitizing at $820^{\circ} \mathrm{C}$, where the austenite + ferrite + graphite coexist, for $45 \mathrm{~min}$ and then quenched and austempered at $325^{\circ} \mathrm{C}$ for $45 \mathrm{~min}$.

\section{Taylor Impact Test}

A traditional Taylor impact test facility installed at the Faculty of Production Engineering, Warsaw University of Technology, Poland was used to carry out the high strain deformation 
experiments (see fig. 2). The investigated cylindrical samples was fired with a powder gun against a rigid heat treated Steel anvil. A special velocity recording system was adjusted to measure the velocity of the fired samples before impacting on the rigid anvil. The tests were performed over two ranges of impact velocities, from $\approx 180 \mathrm{~m} / \mathrm{s}$ to $250 \mathrm{~m} / \mathrm{s}$. The investigated samples were machined from the cast blocks into cylindrical shape with $8 \mathrm{~mm}$ diameter and $28 \mathrm{~mm}$ length. According to Taylor assumptions which are described in detailed in different references [5-6], the dynamic yield strength could be calculated using the following equation (Eq.1):

$$
\mathrm{R}_{\mathrm{d}}=\frac{\frac{1}{2} \rho V^{2}\left(1-\frac{l f}{L}\right)}{\left(1-\frac{l f}{L}\right) \ln \left(\frac{L}{l f}\right)}
$$

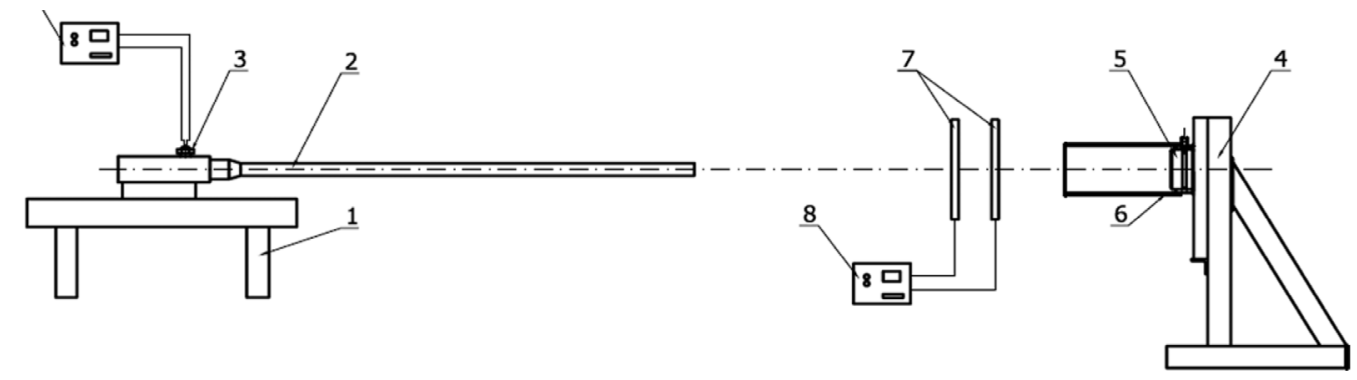

Fig. 2. Schematic drawing of a test stand to determine the dynamic yield stress.

1 - UPB bed, 2 - 12,7 $\mathrm{mm}$ caliber propellant system, 3 - piezoelectric pressure sensor, 4 - pressure plate to fix the ,anvil”, 5 - ,anvil”, 6 - casing pipe, 7 - a set of piezoelectric gates, 8 - velocity recording unit, 9 - powder gas pressure recording unit [5].

\section{Metallographic and XRD analysis}

Conventional metallographic analysis was performed in this investigation by using optical microscope to study the morphological features of the microstructure. XRD analysis was also used to measure the change in the amount of retained austenite and martensite before and after Taylor impact tests. The microstructural phases quantification data before and after each experiment were determined using Rietveld method- MAUD software [7].

\section{Mechanical Testing}

Hardness (bulk and micro hardness), tensile, and impact testing were perfomed on the investigated samples. Three cylindrical tensile samples from each heat treated condition were fabricated from the cast blocks with diameter $6 \mathrm{~mm}$ and gauge length $30 \mathrm{~mm}$ according to ASTM standards E-8.

\section{Results and Discussions}

\section{Microstructure and XRD Analysis}

Figure 3(a-f) illustrates the heat tinted microstructures of the heat treated samples. Generally speaking, austempering at lower temperature i.e. $275^{\circ} \mathrm{C}$, resulted in microstructure with graphite spheroids dispersed in a matrix of very fine ausferrite, as a consequence of enhanced ferrite nucleation at higher degree of undercooling (fig 3a-b). The ferrite phase appears as brown needles whereas the austenite appears as light blue. High austempering temperature i.e. $375{ }^{\circ} \mathrm{C}$ leads to coarsening of the ausferrite from the parent austenite together with the increased $\mathrm{C}$ - diffusion rate render the ferrite to be coarser with feathery morphology. Higher austempering temperatures seem to results in higher volume fraction of retained austenite (fig 3c-d). When the DI was partially austenitized at $820^{\circ} \mathrm{C}$, which lies within the intercritical eutectoid regions interval, where austenite + ferrite + graphite coexist, the microstrucure in this case would be consisted of ausferrite and proeutectoid ferritic islands. As a result of the low austenitizing temperature, the austenite is relatively low in carbon, which raises the $\mathrm{M}_{\mathrm{s}}$ temperature during air quenching, resulting in increased martensite formation (appears like dark blue regions) in both alloyed and unalloyed 
intercritically austempered ductile iron (IADI) (fig 3e-f). The microstructure of the unalloyed IADI samples showed considerable increase in the amount of proeutectoid ferrite compared to that observed in the alloyed IADI samples.

As mentioned before, retained austenite plays a significant role in mechanical properties. The amount of retained austenite $\left(\gamma_{\mathrm{r}}\right)$ in all investigated samples, as determined by XRD, is illustrated in figure (3a-f). The retained austenite reached a maximum level of $36.2 \%$ and $41.8 \%$ in ADI austempered at $375{ }^{\circ} \mathrm{C}$ for unalloyed and alloyed irons respectively. These values are reduced to almost $50 \%$ when decreasing the austempering temperature to $275^{\circ} \mathrm{C}$. Much smaller amounts of $\gamma_{\mathrm{r}}$ were found in the IADI samples, apparently due to the existence of a considerable amount of proeutectoid ferrite. It was found that $\gamma_{\mathrm{r}}$ volume fraction is always higher in alloyed specimens, $\mathrm{Cu}$ and Mo seem to enhance the austenite stability.

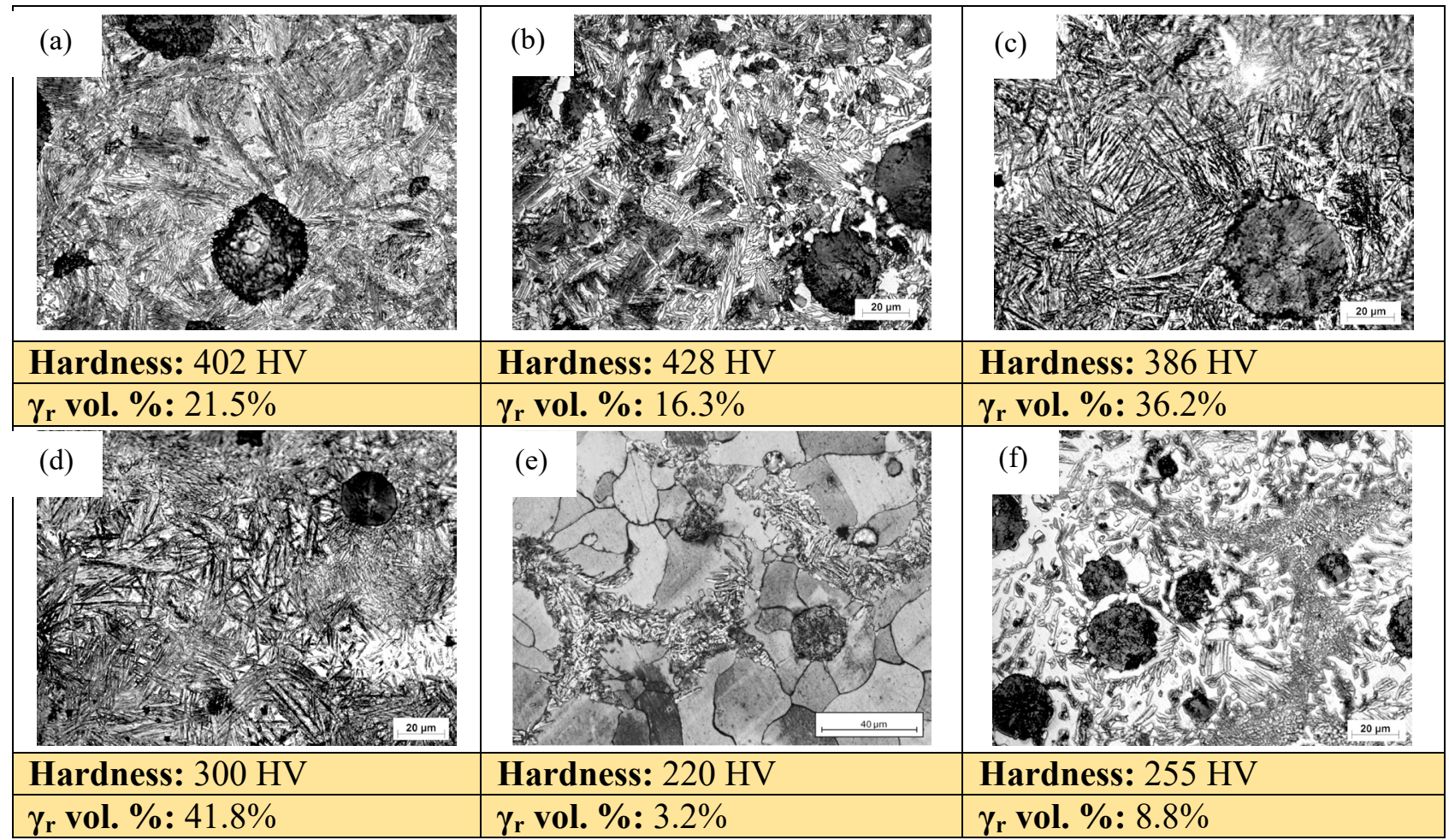

Fig. 3. Microstructure of Taylor impact samples; a) unalloyed ADI austempered at $275^{\circ} \mathrm{C}$ b)alloyed $\mathrm{ADI}$ austempered at $275^{\circ} \mathrm{C}$, c)unalloyed $\mathrm{ADI}$ austempered at $375^{\circ} \mathrm{C}$, d) alloyed ADI austempered at $375^{\circ} \mathrm{C}$ e)unalloyed IADI austenitized at $820{ }^{\circ} \mathrm{C}$ then austempering at $325{ }^{\circ} \mathrm{C}$, f) alloyed IADI austenitized at $820^{\circ} \mathrm{C}$ then austempering at $325{ }^{\circ} \mathrm{C}$, at magnification $500 \mathrm{x}$.

\section{Mechanical Properties}

The yield, ultimate tensile strength, elongation as well as impact toughness values of the investigated ADI grades are shown in fig 4(a-d). Generally speaking, higher austempering temperature leads to lower levels of ultimate as well as yield strength and higher levels of ductility. In single step ADI grades (375\&275) the alloying resulted in considerable decrease in elongation and so the impact toughness, whereas the strength value was insignificantly affected. However the two alloying elements $\mathrm{Cu}$ and Mo were added only to improve austemperability and to avoid pearlite formation upon quenching. Mo may form carbides in the as cast microstructure, and more seriously, it remarkably segregates to the intercellular area, where it drastically hinders the austempering transformation and leads to heterogeneous structure with inferior properties. Therefore, Mo additions are usually restricted to a maximum value of $0.3 \%$.

Both IADI (1\&2) alloys showed elongation and impact toughness values higher than the conventional ADI grades, apparently, the due to the presence of proeutectoid ferrite, whereas the increased strength is attributed to the reinforcing effect of ausferrite in the structure. The effect of ferrite content in IADI alloys was reported [8-9]. The mechanical properties of IADI is controlled by the interaction between the strain hardening component, i.e., retained austenite and ferrite. 
Increasing the amount of ferrite brings about decreasing the amount of retained austenite. It seems that there is a certain quantity of each phase at which the interaction between them causes the optimum ductility. This interaction between ferrite and retained austenite depends on quantity, distribution and grain size of both phases and additionally the mechanical stability of the retained austenite. All these factors are determined by the heat treatment parameters i.e. austenitizing and austempering temperature and time.

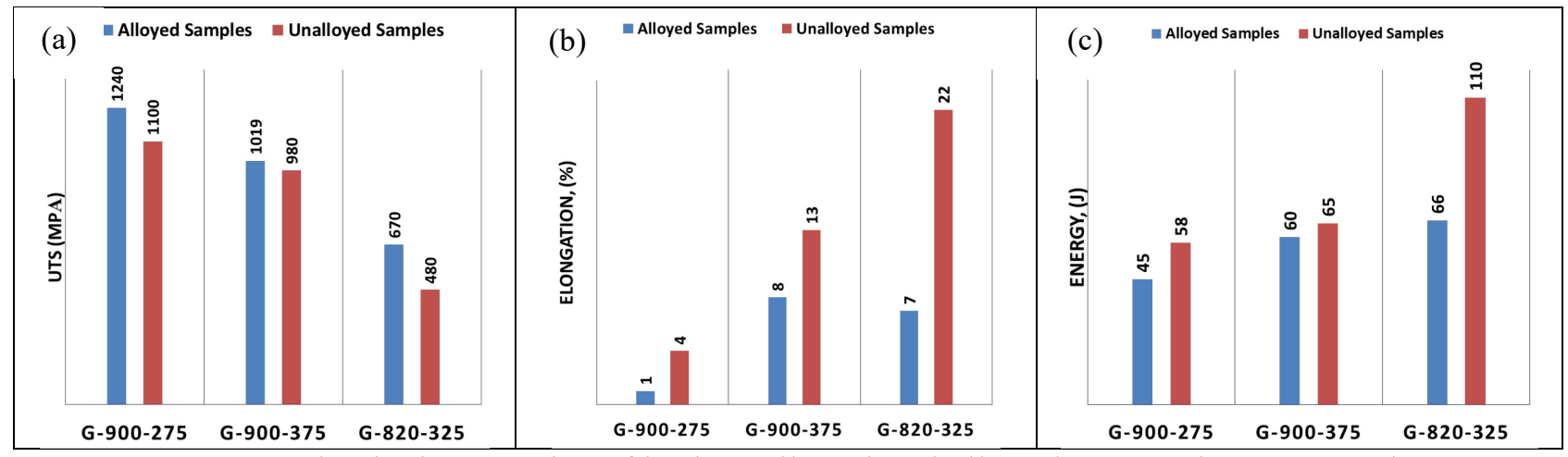

Fig. 4. Mechanical properties of both unalloyed and alloyed ADI and IADI samples.

a)The ultimate tensile strength, b)elongation and c) impact toughness.

\section{Taylor Impact Test Results}

Four grades of the investigated samples were selected for Taylor impact tests. These four represent four different microstrucutres as follows;

- Two alloyed conventional ADI samples, austempered at $275^{\circ} \mathrm{C}$ and $375^{\circ} \mathrm{C}$. These samples were designated as ADI-375 and ADI-275.

- Unalloyed and alloyed IADI samples, austentized at $820{ }^{\circ} \mathrm{C}$ and austempered at $375{ }^{\circ} \mathrm{C}$. These samples were designated as IADI-1 and IADI-2.

Table 1 show the Taylor test parameters and the measured dynamic yield strength which is calculated from equation observed in Eqn.1. In this work, the impact velocity ranges from $170 \mathrm{~m} / \mathrm{s}$ to $180 \mathrm{~m} / \mathrm{s}$ and from $200 \mathrm{~m} / \mathrm{s}$ to $230 \mathrm{~m} / \mathrm{s}$.

Table 1. After impact measurements of the ADI and IADI samples.

\begin{tabular}{|c|c|c|c|c|c|c|c|}
\hline $\begin{array}{c}\text { Shoot } \\
\text { No }\end{array}$ & $\begin{array}{c}\text { Sample } \\
\text { No }\end{array}$ & $\begin{array}{c}\text { Denisty } \rho \\
\text { (Kg/m3) }\end{array}$ & $\begin{array}{l}\text { Speed } \\
\text { V (m/s) }\end{array}$ & $\begin{array}{l}\text { Initial } \\
\text { Length L } \\
\quad(\mathbf{m m})\end{array}$ & $\begin{array}{l}\text { Length after } \\
\text { impact Lf } \\
\text { (mm) }\end{array}$ & $\begin{array}{l}\text { Dynamic } \\
\text { Yield } \\
\text { Strength } \\
\text { (MPa) }\end{array}$ & $\begin{array}{l}\text { Deformation / } \\
\text { Failure Mode }\end{array}$ \\
\hline \multicolumn{8}{|c|}{ Low impact velocity $\approx 170-180 \mathrm{~m} / \mathrm{s}$} \\
\hline 1 & ADI-375 & 7040 & 177.8 & 27.9 & 26.2 & 1352.5 & Mushrooming \\
\hline 2 & ADI-275 & 7066 & 183.3 & 27.9 & 26.4 & 2182.3 & Mushrooming \\
\hline 3 & IADI-1 & 7005 & 171 & 27.9 & 25.1 & 651.3 & Mushrooming \\
\hline 4 & IADI-2 & 7116 & 183 & 27.9 & 25.8 & 1132.8 & Mushrooming \\
\hline \multicolumn{8}{|c|}{ High impact velocity $\approx 200-230 \mathrm{~m} / \mathrm{s}$} \\
\hline 5 & ADI-375 & 7045 & 234.8 & 27.9 & 24.8 & 1201.6 & Mushrooming \\
\hline 6 & ADI-275 & 7066 & 237.9 & 27.9 & - & - & Fragmentation \\
\hline 7 & IADI-1 & 7031 & 231.2 & 27.9 & 23.3 & 691.6 & Shear Cracking \\
\hline 8 & IADI-2 & 7111 & 208.1 & 27.9 & 24.8 & 946 & $\begin{array}{c}\text { Shear Cracking + } \\
\text { Fragmentation }\end{array}$ \\
\hline
\end{tabular}

\section{Deformation / Fracture Modes after Impact}

Structural measurements of the deformed ADI and IADI samples are summarized in Table 1. As seen, with increasing impact velocities, several deformation and fracture modes could be observed, i.e., mushrooming, shear cracking, and fragmentation. According to the different experimental condition, these modes are described in the following;

- Mushrooming: it takes place when a sample impacts on the anvil at a relatively low velocity. Immediately upon impact, both elastic and plastic waves are generated at the impact interface. They propagate and reflect from the tip to the back of the projectile, which results in 
mushrooming deformation like what happened in shoots no 1-4 and 5 (see fig.6a). It is noteworthy that alloyed ADI-375 clearly shows a mushrooming mode without any observed shear cracks despite the high velocity impact that reached up to $230 \mathrm{~m} / \mathrm{s}$ and this may be attributed to the high impact toughness (up to $\approx 60 \mathrm{~J}$ ) with high tensile strength value $(\approx 1000 \mathrm{Mpa})$.

- Shear Cracking and fragmentation: it takes place when a sample impacts on the anvil at relatively high speed. What happens is that the ductility of the sample is not high enough and the mushroomed sample head suffers from shear cracking before the sample head yields too much strain and in some cases the sample's head can be shattered into pieces, shoots no 6-8 clearly show shear cracking and fragmentation failure (see fig $5 \mathrm{~b}-\mathrm{c}$ ).

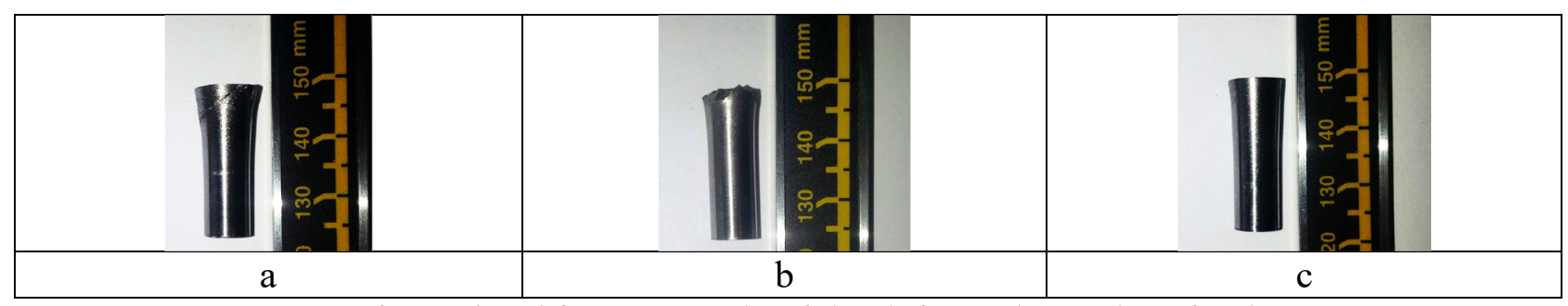

Fig. 5. Deformation / fracture mode of the deformed samples after impact.

a) shear cracking mode- Shoot no 7, b) fragmentation-shoot no 6, c) mushrooming shoot no 2 .

\section{Dynamic Yield Strength Analysis}

Fig. 6 illustrates how the dynamic yield strength that was calculated from Taylor tests depends on the microstructure constituents of the tested material. Some remarks were concluded from the illustrated data;

- Conventional ADI grades (375\&275) seem to have excellent dynamic yield strength values. ADI-275 showed superior dynamic yield strength values $\approx 2182.3 \mathrm{MPa}$, These surprisingly high dynamic yield strength values can compete with those of most alloyed bainitic steels.

- The two IADI grades showed the lowest dynamic yield strength values which ranged between $651.3 \mathrm{MPa}$ (unalloyed) IADI to $946 \mathrm{MPa}$ (alloyed IADI).

- The maximum dynamic to static yield strength ratio reached about 2.2 by the IADI-2 at the low velocity impact of $183 \mathrm{~m} / \mathrm{s}$.

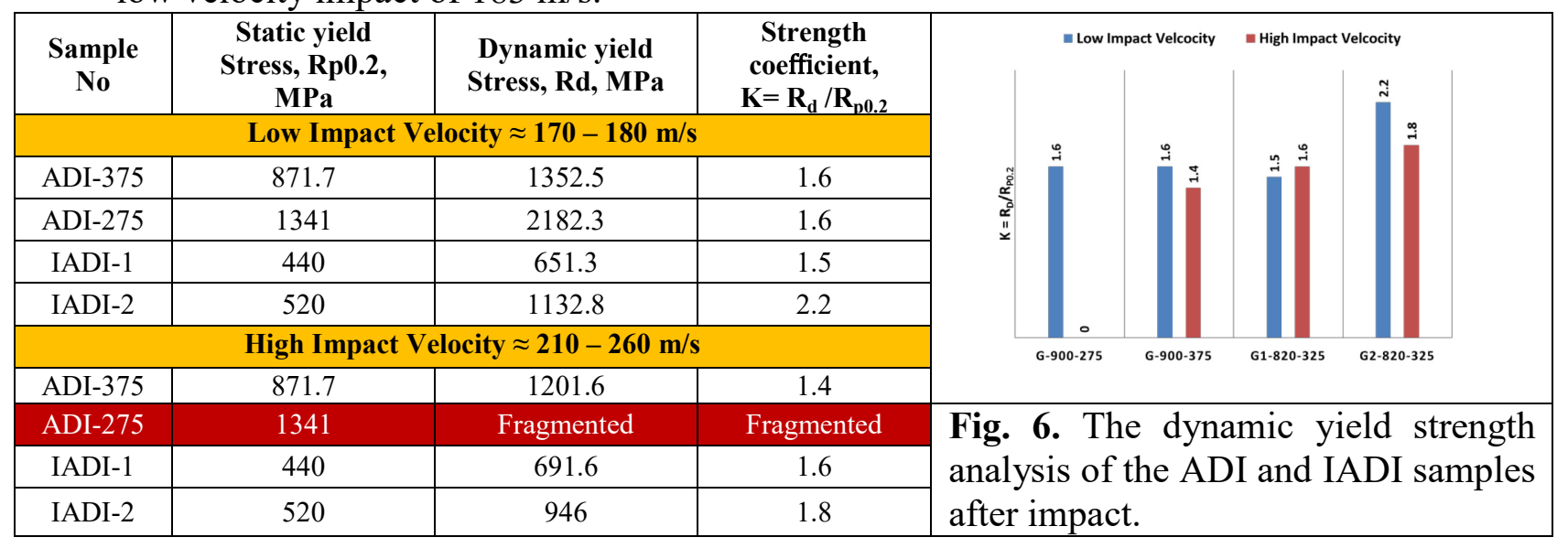

\section{TRIP Phenomenon during High Strain Deformation}

In order to confirm the strain hardening dependence of martensite formation, the retained austenite as well as the martensite content in the microstructure of ADI-275 and ADI 375 alloys after high strain rate deformation impact were determined by XRD. Micro-hardness profile along the sample axis and heat tinted microstructure were also used to confirm the decisive role of strain hardening of ADI.

Optical microstructure, microhardness profile and XRD diffraction studies of ADI-375 are shown in fig 7, increasing amount of martensite at the mushrooming zone can be clearly observed. XRD diffraction patterns showed that alloy ADI-375, started with about $1.2 \%$ martensite and about 
$41.8 \%$ retained austenite in the original structure before impact. After high deformation impact, the amount of martensite in ADI-375 alloy greatly increased with increasing strain rate and finally reached to $18.4 \%$ and $27.2 \%$ at low and high impact velocity respectively. On the other hand, ADI-275 started with about $8.3 \%$ martensite before impact, and clearly all the retained austenite in the original structure (about $\sim 17 \%$ ) was subjected to martensitic transformation to reach a total level of martensite of $\sim 24 \%$, at mushrooming zone, which is very close to the martensitic level reached by ADI-375 at the same zone. This result shows that TRIP phenomenon in ADI is more evident as the ADI-275 and ADI-375 alloys reached the same martensite level (around 25\%) after high deformation impact at the mushrooming zone.

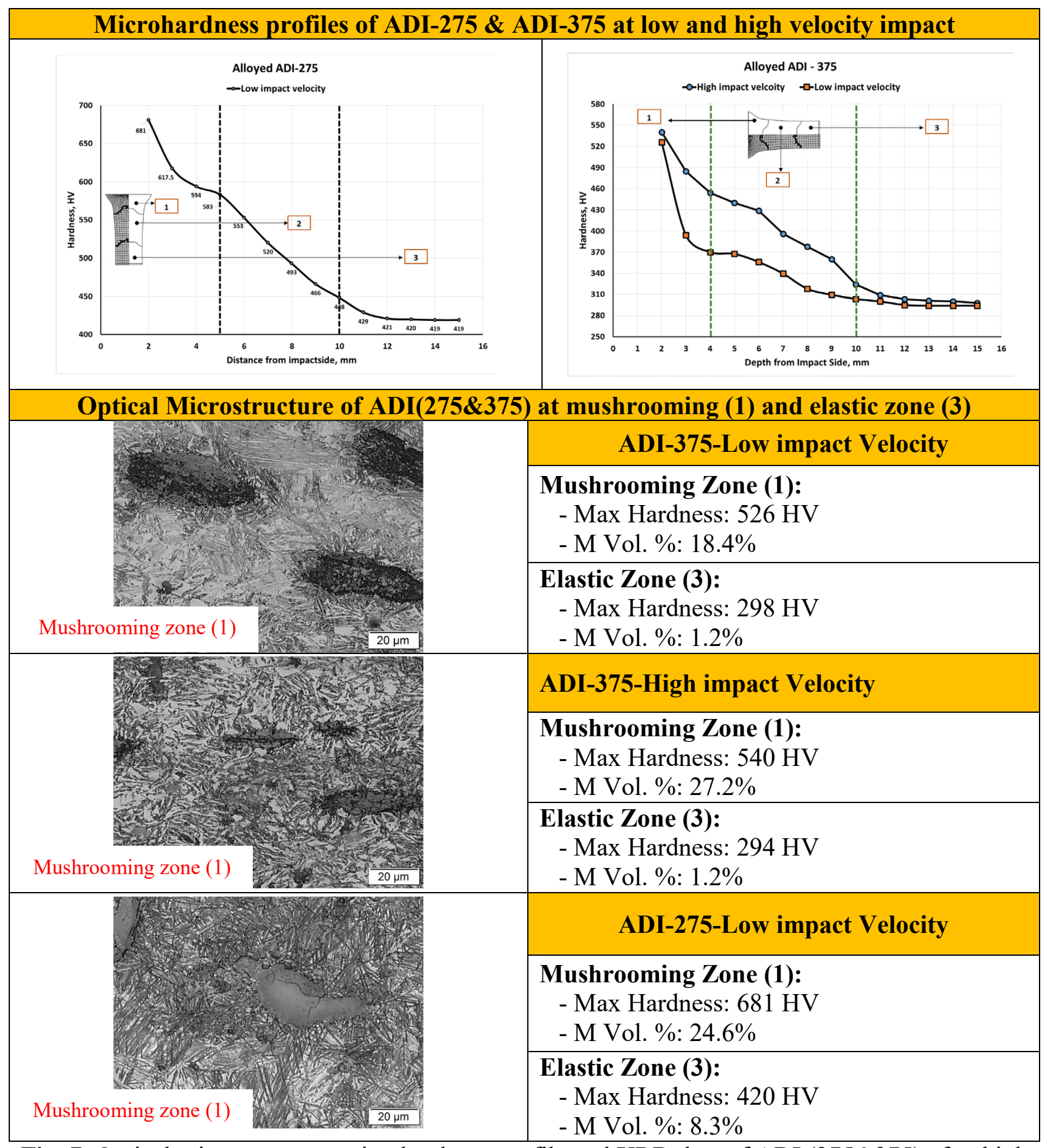

Fig. 7. Optical microstructure, microhardness profile and XRD data of ADI (275\&375) after high deformation impact. 


\section{Summary}

- Taylor impact method was used as a reliable method for studying the high strain deformation of different metals and alloys.

- Several deformation and fracture modes have been observed in the ADI samples after high rate deformation impact, i.e., mushrooming, shear cracking, and fragmentation.

- Samples austempered at high temperatures -ADI/375- have a greater tendency to produce strain induced martensite due to the large amount and grain size of retained austenite which reached up to $36 \%$. This large amount of retained austenite is easily transformed to martensite with final amount of about $9 \%$ after the high dynamic deformation.

- Meanwhile, samples austempered at low temperatures - ADI/275 - revealed fine austenite, as well as large amount of ferrite in close proximity to the austenite, which limits the formation of strain-induced martensite after high velocity impact.

- Intercritically austenitizing ductile iron - IADI - showed the largest mushroom zone among all investigated ADI grades, due to the presence of large amount of proeutectoid ferrite in the microstructure.

\section{Acknowledgment}

This Work was conducted in the frame of scientific collaboration program between the Egyptian Academy of Scientific Research and the Polish Academy of Science.

\section{References}

[1] K.P. Staudhammer, L.E. Murr, M.A. Maeyers, Fundamentals Issues and Applications of ShockWave and High-Strain-Rate Phenomena, 1st edition, ELSEVIER, 2001.

[2] J. Yang, S. K. Putatunda, Influence of a novel two-step austempering process on the strainhardening behavior of austempered ductile cast iron (ADI), Mat. Sci. Eng. A-Struct. 382 (2004) 265-279.

[3] J. Yang, S. K. Putatunda, Improvement in Strength and Toughness of Austempered Ductile Cast Iron by a Novel Two-Step Austempering Process, Materials and Design 25 (3) (2004) 219-230.

[4] S. Daber, P. Prasad Rao, Formation of strain-induced martensite in austempered ductile iron, J. Mater. Sci. 43 (2008) 357-367.

[5] D. Myszka, L. Cybula, A. Wieczorek, Influence of heat treatment conditions on microstructure and mechanical properties of austempered ductile iron after dynamic deformation test, Arch. Metall. Mater. 59 (3) (2014) 1171-1179.

[6] D. Myszka, T. Cybula, The comparison of the microstructure and the mechanical characteristics of austempered ductile cast iron and steel subject to dynamic deformation using the Taylor test, Transactions of foundry research institute T.53 (3) (2013) 73-82.

[7] MAUD software: Materials Analysis Using Diffraction, http://www.maud.radiographema.eu.

[8] M. Soliman, H. Ibrahim, A. Nofal, H. Palkowski: Effect of thermomechanical processing parameters on phase transformation and hardness of dual matrix ductile iron, Int. J. Cast Metal. Res. 29 (1-2) (2016) 79-84.

[9] M. Soliman, H. Ibrahim, A. NOFAL, H. Palkowski, Thermo-mechanically processed dual matrix ductile iron produced by continuous cooling transformation, J. Mater. Process. Tech. 227 (2016) 1-10. 